\title{
POPULAR AND ECONOMIC ENTOMOLOGY.-No. 2.
}

THE APPle TREE TENT Caterpillar - THE AMERICAN LACKEy MOTH

(Clisiocampa Americana HAR.)

BY JAMES FLETCHER, OTTAWA.

There are two kinds of caterpillars which every year commit serious depredations in our Canadian apple orchards, although they by no means confine their attentions to that tree. These are the larvæ of the American

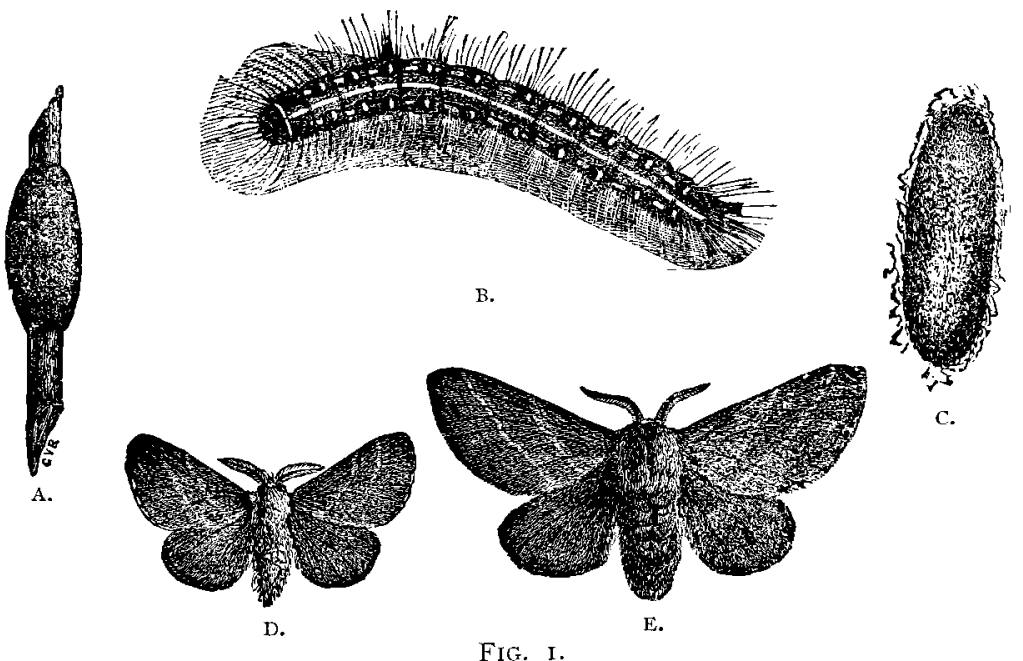

FIG. I.

and Forest Lackey Moths, two species of brown moths which frequently fly into houses at night during July, and draw attention by their headlong, reckless flight, dashing themselves against the ceiling and the walls, and very often finishing up by getting into the lamp chimney. Speaking generally, there is a great resemblance between these two insects in appearance and habits, and the same remedies are applicable for both ; when examined carefully, however, they differ considerably in all their stages, and may be easily recognized. They belong to the Bombycidce or 
Spinners, a family which contains the silkworm moths and several other thick-bodied, hairy moths, with large wings but small heads, bearing comb-like antenna and having the mouth parts imperfect, or as in those now under consideration not developed at all. The caterpillars of the Bombycidce are usually hairy or tufted, and when full grown spin a cocoon for the protection of the short, thick chrysalids.

At Fig. I the different stages of the American Lackey Moth are given. This species appears in the perfect state in the beginning of July, about a week earlier than the other species referred to above, which is known by the name of the Forest Tent Caterpillar C. disstria Hüb. (C. sylvatica Har.)

The American Lackey Moth is a precty species of a dull but rich reddishbrown colour, having the upper wings crossed obliquely by two clear, whitish, parallel lines. In rare instances these show faintly on the lower wings also. The fringes of the wings are chiefly of the same colour as the oblique lines. The space enclosed between the light lines is paler than the rest of the wings in the males, but of the same colour or rather darker in the females. On the under side, all four wings are crossed by a welldefined, irregular, whitish bar. The perfect insects having their mouth parts undeveloped partake of no food, but devote the whole period of their short lives to the perpetuation of their kind As soon as they have paired and the females have laid their eggs they die. The eggs are deposited in rings upon the smaller twigs of various trees, usually within a short distance of the tips. Each egg-cluster contains from 200 to 300 eggs, which, when laid, are covered with a liquid glutinous substance which soon dries and cements them firmly together, and protects them from the weather.

A surprising point in the life history of these insects is that about a month after the eggs are laid, the young caterpillar is fully formed inside the egg and it remains in this condition all through the winter, only eating its way out from the egg in the following spring when the leaves expand. Immediately upon hatching the young caterpillars consume the glutinous covering of the eggs, and then lose no time in attacking the foliage. They at once begin the construction of their tent, which is a web of fine silk, spun in the nearest fork of the twig upon which they were hatched. This tent is increased in size as the caterpillars grow, and if left undisturbed is sometimes nearly a foot in diameter. The caterpillars are very regular in their habits, marching out in regular procession, each following close behind the 
one in front of it. From the habit of the larvæ of this genus of marching out to feed in bodies they are known in Europe as "Processionary Caterpillars." When their appetites are satisfied they return again to their tents to rest. They do not feed at night nor in stormy weather. They usually do not leave their tent until after nine in the morning, and have all returned before sundown. They are generally inactive in the middle of the day.

When full grown the caterpillars are two inches in length, and beautifully marked with black, white, blue, yellow and brown in the pattern shown in Fig. I., B. The continuous stripe down

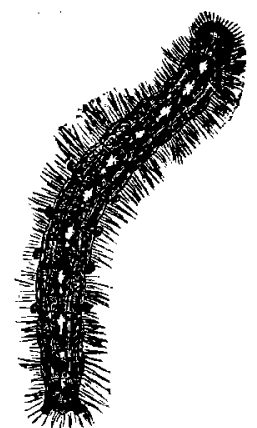

F1G. 2. the back is white, and serves as a distinctive mark by which this species can be known at once from the Forest Tent Caterpillar-Fig. 2 -which has this dorsal stripe broken up into spots. This latter also differs in not constructing a tent, but merely spins a mat of silk on the side of a tree, or upon one of the large branches, on and near which it lives, more or less, in community; but it has not the same social habits as its relative. Just before they spin their cocoons, the caterpillars wander about very much, seeking for a suitable place. The cocoon, Fig. I., C., is greenish yellow, and contains a powdery material like finely ground sulphur. The moths emerge in about eighteen or twenty days after the cocoon is made.

Remedies. - The most successful remedies with these insects all come under hand-picking. During the winter or early spring the egg-clusters can be easily collected and destroyed; they are always laid upon the small twigs and near the tips, so that if a dull day be chosen they can be easily detected against the sky, and can then be cut off and burnt, when, of course, the trees are exempt from attack, until eggs are laid again next year. If this precaution is neglected, the nests, which are conspicuous objects before the foliage is fully expanded in spring, must be cut off and destroyed. An invasion from neighbouring trees can be prevented by tying a strip of cotton-batting round the trunk, which the caterpillars have difficulty in climbing over. 